\title{
ACCEPTANCE SPEECH FOR WORLD MARXIAN ECONOMICS AWARD (I)
}

\author{
David M. Kotz
}

David M. Kotz is Professor of Economics at the University of Massachusetts
Amherst and at the Shanghai University of Finance and Economics. He
specializes in economic crisis theory, social structure of accumulation theory,
the Soviet and post-Soviet Russian economy, and socialist economics. Recent
books: The Rise and Fall of Neoliberal Capitalism (Harvard University Press,
2015), Contemporary Capitalism and Its Crises (Cambridge University Press,
2010), co-edited with Terrence McDonough and Michael Reich, and Russia's
Path from Gorbachev to Putin: The Demise of the Soviet System and the New
Russia (Routledge, 2007), with Fred Weir. Email: dmkotz@econs.umass.edu

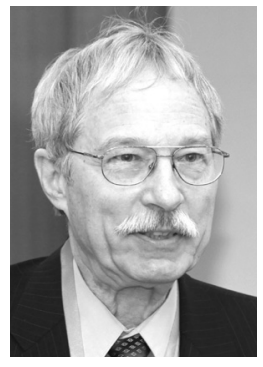

May 24, 2014

I am honored to receive the World Marxian Economics Award from the World Association for Political Economy.

Marxist economics has two aims, as Marx noted: to understand the world and to contribute to changing it. Indeed, if we wish to create a more humane world than that of global capitalism, we must understand how capitalism works, in general and today. Unless we can develop an understanding of contemporary capitalismits main tendencies and contradictions - we cannot hope to devise strategies to overcome it and replace it with socialism.

The dominant economic theory in the world today, neoclassical economic theory, also has two aims. One is to understand capitalism (a market economy as they call it), not to replace it by another system, but to determine the policies required to preserve capitalism. The second aim of neoclassical theory is to make it appear that capitalism is an ideal economic system that assures optimal efficiency, income distribution, economic growth, and technological progress, as well as guaranteeing individual freedom.

Marx referred to the second aspect of neoclassical economics as "vulgar economy." In his day this was represented by Nassau Senior and Jean-Baptiste Say, a tradition carried on in recent times by the neoliberal economists such as Milton Friedman and Robert Lucas. The former aspect of neoclassical economics, which seeks to understand capitalism so as to save it, is represented by such figures as John Maynard Keynes and today Paul Krugman. 
Marxist economists have analyzed various aspects of capitalism, and class society more generally, including, although not limited to, the following aspects: (1) the capital-labor relation, which can be understood using the Marxist theory of value and surplus value; (2) the capital accumulation process and the crises that periodically interrupt the accumulation process stemming from forces within the capitalist system itself; (3) the particular institutional forms that capitalism has taken at different times and places, forms that periodically change based on forces that can be analyzed using Marxist theory; (4) the transitions from one mode of production to another, particularly the transition from capitalism to socialism/ communism as well as the transitions back from socialism to capitalism that have occurred in recent times - transitions that can be explained using Marxist theory and in particular class analysis; (5) the struggle in less developed capitalist countries to develop their economies in the face of already existing powerful developed capitalist states; and (6) the nature of capitalism at the global level, including the theory of imperialism and the analysis of the forces in global capitalism that tend to give rise to wars.

No one can work on every topic. My work has been primarily on topics 2 (accumulation and crisis), 3 (particular institutional forms of capitalism), and 4 (transitions between modes of production). All of my work has in common a focus on explaining, based on Marxist analysis, important economic developments that were unexpected and surprising.

\section{Topic 4: Transitions between Modes of Production}

When the world's first socialist system met its end in the USSR in 1991, it was clear that this event would have a profound effect on Marxist economics and the socialist movement. The dominant interpretations of this event, propounded by neoclassical economists and mainstream Western analysts in political science, history, and Soviet studies, argued that this event resulted from, and indeed proved, the inferiority of socialism compared to capitalism. The more extreme interpretations claimed, against all the evidence, that it showed that socialism could not work in practice - despite more than 50 years of economic progress under Soviet socialism. It was further argued that Marxism was now finally dead.

Along with a secondary co-author, Fred Weir, I undertook a research project in 1992 to determine the real causes of this unexpected development, which gave rise to the book Revolution from Above published in 1997. Using Marxist theory, including the analysis of how contradictions in a social system lead to changes in that system, along with class analysis, we found strong evidence that the Soviet system met its end, not because of a flaw in socialism itself, but due to a contradiction in the particular form of socialism built in the Soviet Union. That 
contradiction was between the economic system of socialism designed to meet the needs of working people on the one hand and the concentration of economic and political power and decision making in a small group of high-level officials who, over time, increasingly became a privileged, self-seeking group. The major part of the ruling group of the Soviet system eventually dismantled socialism in pursuit of greater wealth and power. The whole story of the Soviet demise is more complex than that, but that contradiction lay at the heart of the process.

\section{Topic 2: Accumulation and Crisis}

Seeking to understand the periodic severe economic crises that have occurred in capitalism about every 40 years, I participated in developing the social structure of accumulation (SSA) theory, a theory that was originally proposed by the Marxist economists David Gordon, Michael Reich, Richard Edwards, and Thomas Weisskopf. This theory was inspired by the unexpected world-wide economic crisis that emerged in the 1970s, ending the era of what many had believed was a permanently effective regulated form of capitalism. Beginning in the late 1980s, I wrote a series of articles on the SSA theory aimed at developing, clarifying, and refining the theory so that it can be used effectively to explain long periods of stable accumulation interrupted by severe and long-lasting economic crises. I also participated in editing two books of work by the SSA school along with Terrence McDonough and Michael Reich, published in 1994 and 2010.

\section{Topic 3: Forms of Capitalism}

Around 1980, another unexpected development had occurred: the rise and consolidation of the neoliberal form of capitalism. This seemed a throwback to an earlier, harsher form of capitalism, and it was unclear how such a form of capitalism could bring stable capital accumulation. In the late 1990s, I began to study neoliberal capitalism, using Marxist theory to try to understand this newly arisen form of capitalism. This research project led to a series of articles and now a new book, The Rise and Fall of Neoliberal Capitalism, coming out with Harvard University Press in January 2015. I found that Marxist crisis theory, class analysis, and SSA theory together provided the basis for explaining why and how neoliberal capitalism emerged, how it produced long expansions despite an ever-present realization problem, and how the very factors that produced long expansions were setting the stage for a big economic crisis that finally broke out in 2008 .

My analysis of neoliberal capitalism suggests that the current crisis has created conditions that tend to weaken the hold of neoclassical economics and that are favorable for increasing the influence of Marxist economics. The current crisis also 
has created favorable conditions for the development of the socialist movement around the world, although it also is stimulating the growth of right-wing, nationalist, and neofascist movements as well. If we are successful in launching new efforts to build socialist systems in the near future, I hope that the real lessons of the demise of the Soviet version of socialism will be helpful in the task of building a socialism that will be sustainable over the long run, finally ridding the world of the obsolete system of capitalism as well as consigning neoclassical economic theory to courses in the history of economic thought. 